\title{
Ensayo de PCR multiplex para la detección en leche del género Salmonella, la subespecie I y el serotipo Typhimurium
}

\section{A multiplex PCR assay for detection of genus Salmonella, subspecies I, and serotype Typhimurium in milk}

\author{
Ma. Soledad Vázquez-Garcidueñasa, Silvia Cristina Meléndez-Cejaa, \\ Gerardo Vázquez-Marrufob
}

\begin{abstract}
RESUMEN
Debido a la importancia social y económica de las enfermedades gastrointestinales causadas por alimentos contaminados con Salmonella enterica, es necesario contar con sistemas de detección rápidos, sensibles y específicos para la detección oportuna de dicho patógeno. En este trabajo se presenta un protocolo de PCR de punto final para la identificación de S. enterica en leche, que utiliza los pares de iniciadores STM3098-f2/STM3098r2, STM4057-f/ STM4057-r y STM4497-f/ STM4497-r previamente validados como específicos del género Salmonella, de la subespecie I y del serotipo Typhimurium, respectivamente. El protocolo presentado permite la detección de $1 \mathrm{UFC} / 25 \mathrm{ml}$ de leche contaminada artificialmente, con un periodo de pre-enriquecimiento de $12 \mathrm{~h}$, en ensayos de PCR simple y multiplex con los tres pares de iniciadores. El protocolo diseñado puede ser aplicado en sistemas de vigilancia sanitaria para la detección de $\mathrm{S}$. enterica en leche.
\end{abstract}

PALABRAS CLAVE: Salmonella enterica, Leche, PCR multiplex.

\begin{abstract}
Gastrointestinal diseases caused by foodstuffs contaminated with Salmonella enterica implicate important social and economic issues, making it necessary to have fast, sensitive, and specific systems for opportune detection of the pathogen. An endpoint PCR protocol for identification of $S$. enterica in milk is presented using primer pairs previously validated as specific to the genus Salmonella (STM3098-f2/STM3098-r2), subspecies enterica (subspecies I) (STM4057-f/ STM4057-r), and serotype Typhimurium (STM4497-f/ STM4497-r). This protocol allowed for detection of $1 \mathrm{CFU} / 25 \mathrm{~mL}$ of spiked milk after a $12 \mathrm{~h}$ pre-enrichment period by means of simple and multiplex PCR assay with the three used primer pairs. The designed protocol can be applied in sanitary survey programs for detection of $S$. enterica in milk.
\end{abstract}

KEY WORDS: Salmonella enterica, Milk, Multiplex PCR.

Las enfermedades transmitidas por alimentos representan una de las causas más importantes de morbilidad y mortalidad, tanto en países desarrollados como en aquéllos en vías de desarrollo. Se estima que 1.8 millones de
Diseases transmitted by foodstuffs are among the most important causes of morbidity and mortality in developed as well as in developing countries. It is estimated that 1.8 million people die annually from diarrheic diseases and a large

Recibido el 16 de julio de 2014. Aceptado el 25 de noviembre de 2014.

a División de Estudios de Posgrado, Facultad de Ciencias Médicas y Biológicas "Dr. Ignacio Chávez". Morelia, Michoacán, México.

b Centro Multidisciplinario de Estudios en Biotecnología, Facultad de Medicina Veterinaria y Zootecnia. Universidad Michoacana de San Nicolás de Hidalgo. Km 9.5 carretera Morelia-Zinapécuaro, Col. La Palma, 58893 Tarímbaro. Michoacán, México. Tel, and fax: +52 (443) 2958029 . Correspondencia al último autor. gvazquezmarrufo@yahoo.com.mx. 
personas mueren anualmente a causa de enfermedades diarreicas y una gran proporción de estos casos se puede atribuir a la contaminación de alimentos(1). Entre los principales agentes patógenos causantes de enfermedades diarreicas que se transmiten a través de alimentos se encuentra Salmonella enterica(2), incluidos la leche y los derivados lácteos $(3,4)$. La Organización Mundial de la Salud estima que decenas de millones de casos de salmonelosis no tifoidea ocurren en el mundo anualmente, resultando en más de cien mil muertes(5). La detección oportuna de S. enterica en alimentos lácteos previene el surgimiento de brotes y permite mantener un control adecuado en las cadenas de producción(6).

Además de los métodos microbiológicos estándar para la detección de S. enterica en alimentos, se ha diseñado una gran diversidad de ensayos basados en la PCR tanto de punto final como de tiempo real $(7,8,9)$, algunos de los cuales ya se encuentran disponibles como kits comerciales $(7,10)$. Aunque los ensayos de PCR en tiempo real para la detección de S. enterica en alimentos tienen gran sensibilidad, rapidez y especificidad $(7,8)$, los altos costos de implementación y el nivel de capacitación requerido limitan el acceso a dichas técnicas por las instituciones públicas encargadas de la inocuidad de alimentos y vigilancia sanitaria, manteniendo a los ensayos de PCR de punto final como una opción para la detección de S. enterica en alimentos en países en vías de desarrollo como es el caso de México.

En este trabajo se diseñó un protocolo para la detección de S. enterica en leche, con una sensibilidad 1 unidad formadora de colonia (UFC)/25 ml después de un periodo de preenriquecimiento de $12 \mathrm{~h}$, con los iniciadores STM3098-f2r2, STM4057-fr and STM4497-fr previamente validados como específicos de género, subespecie y serotipo Typhimurium, respectivamente. Sin embargo, no se ha evaluado la utilidad de dichos iniciadores para la detección de $\mathrm{S}$. enterica en alimentos y particularmente en leche. proportion of such deceases are attributable to foodstuff contamination(1). Salmonella enterica is among the main pathogenic agents causing diarrheic diseases that are transmitted by foodstuffs(2), including milk and dairy products $(3,4)$. The World Health Organization estimates that tens of millions of cases of nontyphoideal salmonellosis occur annually worldwide, resulting in over one hundred thousand deaths(5).

The opportune detection of S. enterica in milk and dairy products prevents outbreaks and allows for an adequate control of these foodstuffs production lines(6). Besides, the standard microbiological methods for detection of S. enterica in foodstuffs, a varied assortment of endpoint and real-time PCR assays have been designed for that purpose $(7,8,9)$, some of which are available as commercial kits $(7,10)$. Despite that real-time PCR analyses for detection of S. enterica in foodstuffs are highly sensitive, fast, and specific $(7,8)$, their elevated costs and the level of training needed for its implementation limits its access by public institutions in charge of food safety and sanitary survey, which makes endpoint PCR assays to be an option for detection of $\mathrm{S}$. enterica in foodstuffs in developing countries as Mexico. Furthermore, to the best of our knowledge, there are no reports in the literature of an endpoint or real time multiplex PCR method which detects Salmonella genus, subspecies I and serotype Typhimurium in milk.

We designed a Multiplex PCR protocol for detection of S. enterica in milk that can detect up to 1 colony forming units (CFU)/25 mL after a pre-enrichment period of $12 \mathrm{~h}$, using primer pairs STM3098-f2r2, STM4057-fr and STM4497$\mathrm{fr}$, previously validated as specific for the genus Salmonella, subspecies I, and serotype Typhimurium respectively, and not previously evaluated for their usefulness in detection of the pathogen in foodstuffs, or milk in particular.

Primer pairs used were as those described by Kim et al(11,12): STM3098-f2 (5'-TTTGGCGG 
DETECCIÓN EN LECHE DEL GÉNERO Salmonella LA SUBESPECIE I Y EL SEROTIPO TYPHIMURIUM

Se utilizaron los iniciadores STM3098-f2 (5' TITGGCGGCGCAGGCGATTC-3') y STM3098-r2 (5' -GCCTCCGCCTCATCAATCCG-3'), específicos del género Salmonella; STM4057-f (5' GGTGGCCTCGATGATTCCCG-3') y STM4057-r (5'-CCCACTTGTAGCGAGCGCCG-3'), específicos de la subespecie enterica (subespecie I); STM4497-f (5'-AACAACGGCTCCGGTAATGA-3') y STM4497-r3 (5'-TGACAAACTCTTGATTCTGA$\left.3^{\prime}\right)$, específicos del serotipo Typhimurium, descritos por Kim et al $(11,12)$. En todos los ensayos se utilizó como testigo positivo de amplificación el ADN de la cepa de Salmonella enterica Serotipo Typhimurium (ATCC14028) y como testigo negativo el ADN de la cepa de Escherichia coli (ATCC11229).

Para los ensayos de inoculación artificial se emplearon tres tipos de leche comercial pasteurizada, a las cuales se les hicieron pruebas para la detección de UFC de enterobacterias, generando resultados negativos. Las muestras se conservaron a $4{ }^{\circ} \mathrm{C}$ hasta su análisis. El tiempo entre la adquisición de las muestras de leche y el análisis fue menor a $48 \mathrm{~h}$.

La inoculación con S. enterica de las muestras de leche se realizó de acuerdo a Day et al(13), inoculando $25 \mathrm{ml}$ de leche con diluciones seriadas desde $10^{8}$ hasta 1 UFC. El proceso de pre-enriquecimiento para cada cantidad de UFC probada y el tiempo de incubación analizado se realizó de acuerdo a Oliveira et al(14), empleando $25 \mathrm{ml}$ de leche y $225 \mathrm{ml}$ de agua peptonada (AP) al $1 \%$ a $\mathrm{pH}$ regulado.

La extracción y purificación de ADN para todas las muestras de leche se realizó como se describe a continuación. Se tomaron $500 \mu \mathrm{l}$ de leche y se le adicionaron $500 \mu$ de regulador de lisis (Tris- $\mathrm{HCl} 100 \mathrm{mM}$ a $\mathrm{pH} 8.0$, SDS $2 \%$, $\mathrm{NaCl} 100 \mathrm{mM}$ y EDTA $50 \mathrm{mM}$ ) agitando vigorosamente por $10 \mathrm{~min}$. Enseguida se añadieron $500 \mu \mathrm{l}$ de fenol - cloroformo (1:1 v/v) y se homogenizó durante 5 min en vórtex. Se centrifugó por 10 min a 9,300 xg y se rescató la fase acuosa a la cual se le agregó el mismo volumen de isopropanol frío, incubando por 10
CGCAGGCGATTC-3') and STM3098-r2 (5' GCCTCCGCCTCATCAATCCG-3'), specific for the genus Salmonella; STM4057-f (5' -GGTGGCCTC GATGATTCCCG-3') and STM4057-r (5' CCCACTTGTAGCGAGCGCCG-3'), specific for subspecies enterica (subspecies I); and STM4497-f (5' -AACAACGGCTCCGGTAATGA-3') and STM4497-r3 (5'-TGACAAACTCTTGATTCTGA$3^{\prime}$ ), specific for the serotype Typhimurium. In all assays the amplification of the strain Salmonella enterica serotype Typhimurium (ATCC14028) was used as a positive control and of strain Escherichia coli (ATCC11229) as a negative control.

Assays of spiked milk were made with three different kinds of commercial pasteurized milk which were tested for the presence of enterobacteria CFU, all resulting negative. Samples were stored at 4 oC until their analysis, and all samples were processed within $48 \mathrm{~h}$ after purchase. Milk samples spiking with Salmonella were performed following Day et al procedure(13): $25 \mathrm{ml}$ of milk were inoculated with 10 fold serial dilutions going from $10^{8}$ to 1 CFU. The pre-enrichment period for each CFU tested and incubation time analyzed was established according to Oliveira et al(14), using $25 \mathrm{ml}$ of milk and $225 \mathrm{ml}$ of $1 \%$ buffered peptone water (BPW).

Extraction and purification of DNA from all milk samples was made as follows. To $500 \mu$ of milk, $500 \mu$ of lysis buffer (Tris- $\mathrm{HCl} 100 \mathrm{mM}$ a $\mathrm{pH}$ 8.0, SDS 2\%, $\mathrm{NaCl} 100 \mathrm{mM}$ and EDTA 50 $\mathrm{mM}$ ) were added and vigorously shaken for 10 min. Immediately after, $500 \mu \mathrm{l}$ of phenolchloroform ( $1: 1 \mathrm{v} / \mathrm{v})$ were added and vortexed for $5 \mathrm{~min}$ to homogenize. Samples were later centrifuged for $10 \mathrm{~min}$ at $9,300 \mathrm{xg}$ and the aqueous phase was recovered. An equal volume of cold isopropanol was added to the recovered supernatant and samples were incubated for $10 \mathrm{~min}$ at $-20{ }^{\circ} \mathrm{C}$, after which they were centrifuged at $9,300 \mathrm{xg}$ for $10 \mathrm{~min}$. The supernatant was discarded, the recovered pellet was washed with $250 \mu \mathrm{l}$ of $70 \%$ ethanol, air 
min a $-20{ }^{\circ} \mathrm{C}$. Se centrifugó a 9,300 xg durante 10 min, se desechó el sobrenadante y la pastilla recuperada se lavó con $250 \mu \mathrm{l}$ de etanol al $70 \%$, dejando secar a temperatura ambiente y resuspendiendo en $20 \mu \mathrm{l}$ de agua desionizada esterilizada.

Después de diversos ensayos de optimización, la concentración de los reactivos utilizados en los ensayos de PCR fueron: buffer Tris- $\mathrm{HCl}$ pH $8.510 \mathrm{mM}, \mathrm{MgCl}_{2} 1.50 \mathrm{mM}, 0.4 \mu \mathrm{M}$ de cada iniciador, $0.2 \mathrm{mM}$ de cada dNTP, $25 \mathrm{ng}$ de ADN y $0.5 \mathrm{U}$ de Taq DNA polimerasa (Invitrogen, USA), en un volumen final de $25 \mu \mathrm{l}$. El programa de amplificación empleado tanto para los ensayos de PCR simple como multiplex consistió de un ciclo inicial de 3 min a $94{ }^{\circ} \mathrm{C}$, seguido de 30 ciclos a $94{ }^{\circ} \mathrm{C}$ durante $45 \mathrm{seg}, 65^{\circ} \mathrm{C}$ por 30 seg, $72{ }^{\circ} \mathrm{C}$ por $30 \mathrm{seg}$ y un paso final de 3 min a $72{ }^{\circ} \mathrm{C}(12)$. Tanto el ADN de alto peso molecular obtenido como los productos de amplificación generados se visualizaron mediante electroforesis en geles de agarosa al $2 \%$ y teñidos con bromuro de etidio.

Después de probar tiempos de enriquecimiento de 2 a 24 h, con intervalos de 2 h y 103, 102, 10 y 1 UFC/ 25 ml de leche, se observó que es factible obtener productos de amplificación con los tres pares de iniciadores empleados, en leche contaminada artificialmente hasta con 1 UFC/ $25 \mathrm{ml}$ y un tiempo de pre-enriquecimiento de $12 \mathrm{~h}$ (Figuras 1, A,B,C). En estas mismas muestras y usando el mismo programa de amplificación, se generó un ensayo multiplex con los tres iniciadores (Figura 1, D). En este ensayo de PCR multiplex se obtuvo amplificación positiva en leche contaminada artificialmente en una concentración de 1 UFC/25 ml con un tiempo de pre-enriquecimiento de $12 \mathrm{~h}$ (Figura 1 , D). Tanto los ensayos de PCR simple como multiplex fueron reproducibles, generando los mismos resultados de la Figura 1 en cinco ensayos independientes para cada tipo de iniciador y en el ensayo multiplex.

Otro par de iniciadores también denominados STM4497 distintos a los empleados aquí, pero dried at room temperature, and resuspended in $20 \mu \mathrm{l}$ of sterilized deionized distilled water.

After optimization, the established concentrations of reagents used for assays were: $10 \mathrm{mM}$ Tris$\mathrm{HCl} \mathrm{pH} 8.5$ buffer, $1.50 \mathrm{mM} \mathrm{MgCl} 2,0.4 \mu \mathrm{M}$ of each primer, $0.2 \mathrm{mM}$ of each dNTP, $25 \mathrm{ng}$ of DNA, and $0.5 \mathrm{U}$ de Taq DNA polymerase (Invitrogen ${ }^{\circledR}$, USA), in a final volume of $25 \mu$ l. The amplification program used both for single and multiplex PCR assays was as follows: one initial cycle of $3 \mathrm{~min}$ at $94{ }^{\circ} \mathrm{C}, 30$ cycles at 94 oC for $45 \mathrm{sec}, 65{ }^{\circ} \mathrm{C}$ for $30 \mathrm{sec}, 72$ oC for 30 $\mathrm{sec}$, and a final step of $3 \mathrm{~min}$ at $72{ }^{\circ} \mathrm{C}(12)$. Both high molecular weight DNA and amplification products were visualized by electrophoresis in $2 \%$ agarose gels stained with ethidium bromide.

After trials of enrichment times going from 2 to $24 \mathrm{~h}$ at $2 \mathrm{~h}$ intervals, and 103,102,10, and 1 CFU/25 $\mathrm{ml}$ of milk, it was observed that it is possible to obtain amplification products with the three primer pairs used in samples of spiked milk with up to $1 \mathrm{CFU} / 25 \mathrm{ml}$ and a preenrichment time of $12 \mathrm{~h}$ (Figures $1, A, B, C$ ). A multiplex PCR assay was made in the same samples using the three primer pairs and the same PCR protocol (Figure 1, D). The three primer pairs allowed for detection in spiked milk of up to $1 \mathrm{CFU} / \mathrm{ml}$ with a pre-enrichment period of $12 \mathrm{~h}$. Both simple and multiplex PCR assays were reproducible, generating the same results depicted in Figure 1 from five replicas made for each kind of experiment.

Other pair of primers called STM4497 -different from those used in this work, but directed to the same gene- have been used in multiplex PCR assays for detection of S. Typhimurium in samples of water, chicken meat, and beef with sensitivities of $100 \mathrm{CFU} / 100 \mathrm{ml},<60$, and $<50$ $\mathrm{CFU} / \mathrm{mg}$, respectively(15). The primers used by Shanmugasundaram et al(15) and those used by $\mathrm{Kim}$ et al $(11,12)$, which were those used in this work, reinforce the specificity for serotype Typhimurium of the STM4497 genetic region, and hence its usefulness for specific detection of serotype Typhimurium in samples 
dirigidos al mismo gen, han sido empleados en ensayos de PCR multiplex para la detección de S. Typhimurium en muestras de agua, carne de pollo y de res, con una sensibilidad de 100 UFC/ $100 \mathrm{ml},<60$ y $<50 \mathrm{UFC} / \mathrm{mg}$, respectivamente(15). Tanto los iniciadores empleados por Shanmugasundaram et al(15) como los de Kim et al $(11,12)$ usados en este trabajo, reafirman la especificidad de la región genética STM4497 como espećfica del serotipo Typhimurium, y por lo tanto, su utilidad para la detección específica de dicho serotipo en muestras de alimentos. Los tres pares de iniciadores pueden emplearse de manera independiente o en un ensayo multiplex, si interesa saber si el serotipo contaminante es Typhimirum, ya que dicho serotipo es el que más comunmente se encuentra contaminando leche y productos lácteos(3).

La sensibilidad obtenida por el ensayo aquí diseñado en leche contaminada artificialmente es superior a la reportada por Shanmugasundaram et al(15) en agua y carne. La sensibilidad reportada para otros ensayos de PCR simple o multiplex para determinar la presencia de S. enterica en leche contaminada artificialmente es 1-10 UFC/ml empleando iniciadores dirigidos al gen invA(16).

Previamente se ha reportado que la incubación directa de S. enterica en leche durante $12 \mathrm{~h}$ puede detectar $10^{2} \mathrm{UFC} / \mathrm{ml}$ empleando iniciadores dirigidos al gen de la subunidad 165 de rRNA(17). También se ha notificado un protocolo de detección sin enriquecimiento, en el cual es posible detectar hasta 5 bacterias $/ \mathrm{ml}$ en muestras de leche empleando iniciadores dirigidos al gen hilA(18). La sensibilidad de 1-10 UFC/ml se ha obtenido con un preenriquecimiento $18 \mathrm{~h}$ en caldo de soya $\mathrm{y}$ triptona(16). Las $12 \mathrm{~h}$ de pre-enriquecimiento en AP al 1\% aseguran la detección hasta de 1 UFC/25 ml de leche, lo cual está por arriba de los límites de detección reportados previamente en ensayos de PCR de punto final.

En otro trabajo se ha reportado el uso de centrifugación para recuperar el pellet bacteriano
Figura 1. Sensibilidad del ensayo de PCR para la detección de Salmonella enterica en leche

Figure 1. Sensitivity of the PCR assay for detection of Salmonella enterica in milk

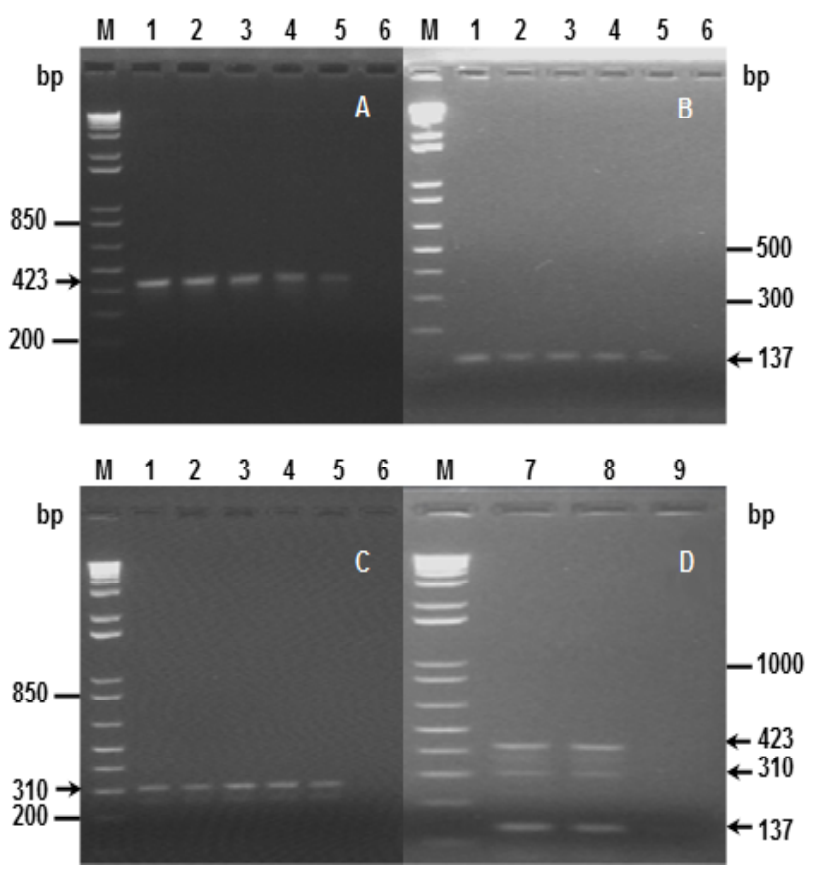

$2 \%$ agarose gel stained with ethidium bromide showing amplicons obtained using the primer pairs STM3098 (A), STM4057 (B), and STM4497 (C) specific for the genus Salmonella, subspecies enterica, and serotype Typhimurium, respectively, and the three primers in a multiplex assay (D). Lanes: M, molecular weight markers (1 Kb Plus DNA Ladder, Invitrogen USA); 1, positive control DNA (Salmonella enterica Serotype Typhimurium ATCC14028); 2-5, DNA from milk samples spiked with $10^{3}$, $10^{2}, 10$, and $1 \mathrm{CFU} / 25 \mathrm{ml}$, respectively, and enriched during $12 \mathrm{~h} ; 6$ and 9, negative control DNA (E. coli, ATCC11229); 7 and 8, DNA from independent milk samples spiked with $1 \mathrm{CFU} / 25 \mathrm{ml}$, and enriched during $12 \mathrm{~h}$. Arrowheads indicates amplicon size obtained for each primer pair.

of foodstuffs. The three pairs of primers used in this work can be used either independently or in multiplex assays, when it is of interest to determine contamination by serotype Typhimurium, which is the most common serotype found contaminating milk and dairy products(3).

The sensitivity in spiked milk that was obtained in the designed assay is greater to that reported by Shanmugasundaram et al(15) in water and meat. Previously reported sensitivities for other 
y un tratamiento con EDTA y TritónX-100 para eliminar grasas y proteínas que inhiben la $\operatorname{PCR}(18)$, lo cual no fue necesario en el presente trabajo.

En conclusión, el protocolo aquí reportado es superior en sensibilidad, especificidad y rapidez a otros protocolos de PCR de punto final para la detección de $\mathrm{S}$. enterica en leche. Adicionalmente, es de esperar que la sencillez del protocolo reportado represente una ventaja adicional para su implementación en sistemas de vigilancia sanitaria por parte de agencias de salud pública de países de escasos recursos.

\section{AGRADECIMIENTOS}

Se agradece al CONACYT por la beca de maestría otorgada a Silvia Cristina MeléndezCeja (No. de becario 253389). El presente trabajo fue financiado por el proyecto SALUD2009-01-115172 del Fondo sectorial de investigación en salud y seguridad social SSA I MSS/ISSSTE-CONACYT, CONVOCATORIA 2009.

\section{LITERATURA CITADA}

1. Stein C, Kuchenmüller $T$, Hendrickx S, Prüss-Üstün $A$, Wolfson L, Engels D, Schlundt J. The global burden of disease assessments-WHO is responsible? PLoS Negl Trop Dis $2007 ; 1(3)$ : e161.

2. Newell DG, Koopmans M, Verhoef L, Duizer E, Aidara-Kane A, Sprong $\mathrm{H}$, et al. Food-borne diseases - The challenges of 20 years ago still persist while new ones continue to emerge. Int J Food Microbiol 2010; 139:S3-S15.

3. Oliver SP, Boor $\mathrm{KJ}$, Murphy SC, Murinda SE. Food safety hazards associated with consumption or raw milk. Foodborne Pathog Dis 2009;6:793-806.

4. Langer AJ, Ayers T, Grass J, Lynch M, Angulo FJ, Mahon BE. Nonpasteurized dairy products, disease outbreaks, and state laws-United States, 1993-2006. Emerg Infect Dis 2012; 18:385-391.

5. WHO (2013) http://www.who.int/mediacentre/factsheets/ fs139/en/index.html. Accessed: 1st Dec, 2013.

6. Papademas P, Bintsis T. Food safety management systems (FSMS) in the dairy industry: A review. Int J Dairy Technol 2010;63:489-503. simple or multiplex PCR assays using primers directed to the invA gene for determining the presence of S. enterica in spiked milk ranged between 1 and $10 \mathrm{CFU} / \mathrm{ml}^{(16)}$.

It has been reported that direct incubation in milk of S. enterica for $12 \mathrm{~h}$ can detect $10^{2} \mathrm{CFU} /$ $\mathrm{ml}$ using primers directed to the $16 \mathrm{~S}$ subunit rRNA gene(17). Also reported is a protocol for detection without pre-enrichment using primers directed to the hilA gene that is able to detect up to 5 bacteria/ml in milk samples(18). A sensitivity of $1-10 \mathrm{CFU} / \mathrm{ml}$ has been obtained with a pre-enrichment period of $18 \mathrm{~h}$ in tryptone soya broth(16). The $12 \mathrm{~h}$ pre-enrichment period in $1 \%$ BPW used ensures detection of up to $1 \mathrm{CFU} / 25 \mathrm{ml}$ of milk, which is already beyond the detection limits previously detected for endpoint PCR assays. Other work has used centrifugation for recovering the bacterial pellet and a treatment with EDTA and TritonX-100 for elimination of lipids and proteins that inhibit PCR(18), a procedure that was unnecessary in this work.

In conclusion, the protocol here presented is superior in sensitivity, specificity, and rapidity compared to other endpoint PCR protocols for detection of S. enterica in milk. The simplicity of this protocol is expected to provide an added advantage in its implementation for sanitary survey programs of public health agencies from low-income countries.

\section{ACKNOWLEDGEMENTS}

We acknowledge CONACYT for granting a M.Sc. scholarship to Silvia Cristina Meléndez-Ceja (No. 253389). This work was financed by the project SALUD- 2009-01-115172 of the Fondo Sectorial de Investigación en Salud y Seguridad Social SSAIIMSS/ISSSTE-CONACYT, CONVOCATORIA 2009.

End of english version 
7. Maurer JJ. Rapid detection and limitations of molecular techniques. Annu Rev Food Sci Technol 2011;2:259-279.

8. Logue CM, Nolan LK. Emerging bacterial food-borne pathogens and methods of detection. In: Simpson BK, et al, editors. Food Biochemistry and Food Processing, 2nd ed., New York: John Wiley \& Sons, Inc; 2011:833- 857.

9. Riyaz-Ul-Hassan S, Verma $\vee$ and Qazi GN. Real-time PCRbased rapid and culture-independent detection of Salmonella in dairy milk - addressing some core issues. Lett Appl Microbiol 2013; 56:275-282.

10. Glynn B, Lahiff S, Wernecke M, Barry T, Smith TJ, Maher M. Current and emerging molecular diagnostic technologies applicable to bacterial food safety. Int J Dairy Technol 2006; 59: 126-39.

11. Kim HJ, Park SH, Kim HY. Comparison of Salmonella enterica serovar Typhimurium LT2 and non-LT2 Salmonella genomic sequences, and genotyping of Salmonellae by using PCR. Appl Environ Microbiol 2006; 72:6142-6151.

12. Kim HJ, Park SH, Lee TH, Nahm BH, Chung YH, Seo KH, Kim HY. Identification of Salmonella enterica serovar Typhimurium using specific PCR primers obtained by comparative genomics in Salmonella serovars. J Food Prot 2006; 69: 1653-1661.

13. Day JB, Basavanna U, Sharma SK. Development of a cell culture method to isolate and enrich Salmonella enterica serotype Enteritidis from shell eggs for subsequent detection by Real-Time PCR. Appl Environ Microbiol 2009; 75:5321-5327.

14. Oliveira SD, Rodenbusch CR, Cé MC, Rocha SLS, Canal CW. Evaluation of selective and non-selective enrichment PCR procedures for Salmonella detection. Lett Appl Microbiol 2003; 36:217-221.

15. Shanmugasundaram M, Radhika M, Murali HS, Batra, HV. Detection of Salmonella enterica serovar Typhimurium by selective amplification of fliC, fljB, iroB, invA, rfbJ , STM2755, STM4497 genes by polymerase chain reaction in a monoplex and multiplex format. World J Microbiol Biotechnol 2009; 25:1385-1394.

16. Balakrishna, K, Murali HS, Batra HV. A novel multiplex polymerase chain reaction for simultaneous detection of Yersinia enterocolitica, Staphylococcus aureus, Aeromonas and Salmonella from chicken meat and milk samples. J Food Safety 2010;30:263-275.

17. Aslam M, Hogan J, Smith KL. Development of a PCR-based assay to detect shiga toxin-producing Escherichia coli, Listeria monocytogenes, and Salmonella in milk. Food Microbiol 2003; 20:345-350.

18. Marathe SA, Chowdhury R, Bhattacharya R, Nagarajan AG, Chakravortty D. Direct detection of Salmonella without preenrichment in milk, ice-cream and fruit juice by PCR against hilA gene. Food Control 2012;23:559-563. 
